University of Nebraska - Lincoln

DigitalCommons@University of Nebraska - Lincoln

Agronomy \& Horticulture - Faculty Publications

Agronomy and Horticulture Department

2011

Effect of Nitrogen Fertilizer Rate and Harvest Season on Forage

Yield, Quality, and Macronutrient Concentrations in Midland

Bermuda grass

\author{
Maru K. Kering \\ Samuel Roberts Noble Foundation, mkkering@noble.org \\ John A. Guretzky \\ University of Nebraska-Lincoln, jguretzky2@unl.edu \\ Eddie Funderburg \\ Samuel Roberts Noble Foundation, Ardmore, OK, erfunderburg@noble.org \\ Jagadeesh Mosali \\ Samuel Roberts Noble Foundation, Ardmore, OK, jmosali@noble.org
}

Follow this and additional works at: https://digitalcommons.unl.edu/agronomyfacpub

Part of the Plant Sciences Commons

Kering, Maru K.; Guretzky, John A.; Funderburg, Eddie; and Mosali, Jagadeesh, "Effect of Nitrogen Fertilizer Rate and Harvest Season on Forage Yield, Quality, and Macronutrient Concentrations in Midland Bermuda grass" (2011). Agronomy \& Horticulture -- Faculty Publications. 555.

https://digitalcommons.unl.edu/agronomyfacpub/555

This Article is brought to you for free and open access by the Agronomy and Horticulture Department at DigitalCommons@University of Nebraska - Lincoln. It has been accepted for inclusion in Agronomy \& Horticulture -Faculty Publications by an authorized administrator of DigitalCommons@University of Nebraska - Lincoln. 


\title{
Effect of Nitrogen Fertilizer Rate and Harvest Season on Forage Yield, Quality, and Macronutrient Concentrations in Midland Bermuda grass
}

\author{
Maru K. Kering, ${ }^{1}$ John Guretzky, ${ }^{2}$ Eddie Funderburg, ${ }^{1}$ \\ and Jagadeesh Mosali ${ }^{1}$ \\ 1. Samuel Roberts Noble Foundation, Ardmore, Oklahoma, USA \\ 2. University of Nebraska-Lincoln, Lincoln, Nebraska, USA \\ Corresponding author - M. K. Kering, Noble Foundation, \\ 2510 Sam Noble Parkway, Ardmore, OK 73401; email mkkering@noble.org
}

\begin{abstract}
Bermuda grass [Cynodon dactylon (L.) Pers.] is a major forage for grazing and hay production in the southern United States. The objectives of this study were to determine effects of nitrogen $(\mathrm{N})$ fertilization rate $\left(0,112,224,336\right.$, and $\left.448 \mathrm{~kg} \mathrm{ha}^{-1}\right)$, split spring and summer applications of $\mathrm{N}$ at the 224 and $448 \mathrm{~kg} \mathrm{ha}^{-1}$ rates, and harvest periods (spring and summer) on forage yield, crude protein (CP), acid detergent fiber (ADF), neutral detergent fiber (NDF), total digestible nutrients (TDN), and concentrations of phosphorus $(\mathrm{P})$, potassium $(\mathrm{K})$, magnesium $(\mathrm{Mg})$, and calcium $(\mathrm{Ca})$ in Midland Bermuda grass. Data were collected from 2002 to 2008 as part of an ongoing, long-term soil fertility experiment in southern Oklahoma. Repeated measures analysis of these long-term data showed that forage yield responses to $\mathrm{N}$ rate varied with year and harvest time with up to 2.5-fold yield differences among years. Nitrogen fertilization increased CP, TDN, and macronutrient $\mathrm{P}$ and $\mathrm{Mg}$ and decreased $\mathrm{ADF}$ and NDF. Crude protein was increased by $\geq 50 \%$, and ADF and NDF dropped by up to $25 \%$ with the greatest $N$ rate. In general, split $\mathrm{N}$ applications did not affect forage yield but produced low-quality forage compared to single $\mathrm{N}$ application in spring. Split application of $448 \mathrm{~kg} \mathrm{~N} \mathrm{ha}^{-1}$ gave forage with $\mathrm{CP}$, TDN, ADF, and NDF similar to the Bermuda grass receiving 336 or $448 \mathrm{~kg} \mathrm{~N}^{-1}$ as a single application. Spring forage had better forage quality than summer harvests. While $\mathrm{N}$ fertilization increased forage $\mathrm{Mg}$ and $\mathrm{P}$ concentrations by more than $50 \%$ during both spring and summer, it had no effect or slight increased $\mathrm{K}$ and $\mathrm{Ca}$ concentrations. In the southern Great Plains, despite the weather-dependent variability in forage yield of Bermuda grass, $\mathrm{N}$ application increase forage quality.
\end{abstract}

Keywords Bermuda grass, element concentration, forage quality, harvest period, nitrogen fertilization

\section{Introduction}

Bermuda grass [Cynodon dactylon (L.) Pers.] is an important warm-season grass for pasture and hay production in the southern United States. Considerable efforts have been expended to develop productive cultivars and determine fertilization strategies for optimizing forage yield and quality. Research has shown forage yield and quality of Coastal 
Bermuda grass to be affected by rate, source, and time of application of inorganic nitrogen (N) fertilizer (Morris and Celecia 1962; Woodhouse 1969; Overman, Sanderson, and Jones 1993), poultry litter (Brink, Sistani, and Rowe 2004; Read et al. 2006), swine effluent (Brink, Pederson, and Sistani 2005), and dairy manure compost (Helton et al. 2008). Nitrogen fertilizer rate, source, and time of application effects on yield and quality responses of Midland Bermuda grass, a more cold hardy variety adapted to areas where coastal winter kills, have also been examined (Harlan, Burton, and Elder 1954; Taliaferro, Burton, and Elder 1975; Mathias, Bennett, and Lundberg 1978; Osborne et al. 1999).

Experiments have generally shown Bermuda grass yields and quality respond positively to large rates of $\mathrm{N}$ (Wilkinson and Langdale 1974; Taliaferro, Rouquette, and Mislevy 2004). Coastal Bermuda grass produced forage yields of $30 \mathrm{Mg}^{-1}$ with application of $1200 \mathrm{~kg} \mathrm{~N} \mathrm{ha}^{-1} \mathrm{yr}^{-1}$, common Bermuda grass produced yields of $18 \mathrm{Mg} \mathrm{ha}^{-1}$ with $800 \mathrm{~kg}$ $\mathrm{N} \mathrm{ha}^{-1} \mathrm{yr}^{-1}$, and Midland Bermuda grass produced yields approaching $16 \mathrm{Mg} \mathrm{ha}^{-1}$ with 400 $\mathrm{kg} \mathrm{N} \mathrm{ha}^{-1} \mathrm{yr}^{-1}$ (Wilkinson and Langdale 1974). Increasing the rate of $\mathrm{N}$ application has been reported to increase crude protein (CP) and in vitro dry matter digestibility (IVDMD), while reducing acid detergent fiber (ADF) (Fribourg, Edwards, and Barth 1971; Fribourg et al. 1979; Kellogg et al. 1994). Research has shown that while macronutrient concentrations of unfertilized Coastal Bermuda grass on a Ruston fine, sandy loam soil were low, Bermuda grass receiving more than or equal to $270 \mathrm{~kg} \mathrm{~N}^{-1}$ had forage $\mathrm{N}$, phosphorus $(\mathrm{P})$, and potassium $(\mathrm{K})$ concentrations greater than that considered optimal for beef cows (Read et al. 2006). Research is limited on how $\mathrm{N}$ fertilization rate affects mineral element concentration in Midland Bermuda grass.

Changes in rainfall and temperature may affect the response of Bermuda grass to $\mathrm{N}$ fertilizer application (Fribourg et al. 1979). In a study in Mississippi, Bermuda grass receiving $130 \mathrm{~kg} \mathrm{~N} \mathrm{ha}^{-1}$ produced $2570 \mathrm{~kg} \mathrm{ha}^{-1}$ more forage in a wet than a dry year (Griffin and Watson 1982). Bermuda grass receiving $\mathrm{N}$ fertilization was most productive at above average precipitation in central Texas (Sanderson, Jones, and Newman 1991). In a study in Tennessee, IVDMD of Bermuda grass decreased from spring to summer regardless of whether $\mathrm{N}$ fertilizer was applied (Fribourg et al. 1979). Rainfall affects forage quality because of changes in regrowth patterns, alteration of leaf to stem ratios (Griffin and Watson 1982), and concentration of $\mathrm{N}$ in leaves during dry periods (Prine and Burton 1956). High temperatures generally hasten maturity, increase lignification, and reduce forage quality (Henderson and Robinson 1982).

High summer temperatures and drought are common in the south-central region of the United States. Yet, long-term studies of the effect of $\mathrm{N}$ rates on forage yield and quality of Bermuda grass are limited. In 2002, a long-term soil fertility experiment was established on an existing stand of Midland Bermuda grass in southern Oklahoma to examine how yearly environmental variation affects Bermuda grass responses. Our objective was to document how $\mathrm{N}$ fertilizer rates, split spring and summer applications of $\mathrm{N}$ fertilizer, and harvest season affected forage yield, quality, and mineral element concentrations during the first 7 years of this experiment.

\section{Material and Methods}

\section{Experimental Site and Treatments}

The research was conducted at the Noble Foundation Red River Demonstration and Research Farm near Burneyville, Okla. The parent material at the site was a sand alluvium, and soil was a Minco fine, sandy loam (coarse silty, mixed, superactive, thermic Udic Hap- 
lustolls). The study was established on a Midland Bermuda grass field that had been used for hay production for several years. Soil tested in 2002 had the following physical and chemical characteristics: $\mathrm{pH}$ 5.5; organic matter 1.5\%; and 55, 270, 980, and $270 \mathrm{~kg} \mathrm{ha}^{-1}$ available $\mathrm{P}, \mathrm{K}$, calcium (Ca), and magnesium $(\mathrm{Mg})$, respectively. Plots measuring 3.0 by 4.5 $\mathrm{m}$ were arranged in a randomized complete block design with three replications.

Five $\mathrm{N}$ rates $\left(0,112,224,336\right.$, and $\left.448 \mathrm{~kg} \mathrm{ha}^{-1}\right)$ were applied annually during the spring from 2002 through 2008. Nitrogen rates of 224 and $448 \mathrm{~kg} \mathrm{ha}^{-1}$ were applied either as a single application or split into spring and summer applications. Nitrogen was applied as urea during all spring applications and as ammonium nitrate in summer applications. During all years of study, all plots received 50 and $112 \mathrm{~kg} \mathrm{ha}^{-1}$ of $\mathrm{P}$ and $\mathrm{K}$, respectively. Each spring while Bermuda grass was dormant, plots were sprayed with glyphosate [N(phosphonomethyl) glycine] at $1.12 \mathrm{~kg}$ active ingredient ha ${ }^{-1}$ and 2,4 D-amine (2-4-dichlophenoxyacetic acid) at $2.24 \mathrm{~kg}$ active ingredient $\mathrm{ha}^{-1}$ for control of winter annual broadleaf weeds and annual grasses.

Forage was harvested two to four times per year at inflorescence emergence: stages 31 to 39 (West 1990). Subsamples were collected at each harvest, dried at $60^{\circ} \mathrm{C}$ in a forcedair oven, ground to pass through a $<1-\mathrm{mm}$ screen with a Wiley Mill (Thomas Scientific, Swedesboro, N.J.), and processed for determination of concentrations of CP, ADF, neutral detergent fiber (NDF), TDN, $\mathrm{P}, \mathrm{K}, \mathrm{Mg}$, and $\mathrm{Ca}$.

While CP was determined in all years, ADF, NDF, and TDN determination began in 2005. Forage P, K, Mg, and Ca were determined starting in 2004. From 2002 through 2005, concentration of $\mathrm{N}$ was determined by combustion with the Dumas method (Padmore 1990), P by photometric method (Padmore 1990), and K by atomic absorption spectrophotometric method (Isaac 1990) at Ward Laboratories (Kearney, Neb.). Neutral detergent fiber and ADF were determined by refluxing with neutral and acid detergent solution, respectively. Total digestible nutrients were computed from the equation TDN $=102.7$ (1.114 × ADF). From 2006 through 2008, nutrient concentrations were estimated with nearinfrared reflectance spectroscopy (NIRS) equations developed by the NIRS Forage and Feed Testing Consortium (2007).

Harvested forage was grouped as spring or summer season harvest. Spring harvest refers to harvests done before 21 June while summer refers to alls harvest between 21 June and 10 October each year. There was a single spring harvest in all years, but the number of summer harvests was one in 2004 and 2006, two in 2002, 2003, and 2005, and three in 2007 and 2008. Spring and summer temperature and precipitation were calculated from 1 March through 21 June and 22 June through 30 September, respectively.

\section{Statistical Procedures}

A repeated measures analysis of variance was conducted using the mixed models procedure in SAS (SAS Institute Inc., Cary, N.C.) to examine interactive effects of N fertilizer rate, harvest season, and year on forage yield and quality $(P \leq 0.05)$. Single degree of freedom statements were constructed to contrast effects of single and split applications of $\mathrm{N}$ at the 224 and $448 \mathrm{~kg} \mathrm{~N} \mathrm{ha}^{-1}$ rates.

\section{Results}

\section{Weather Conditions}

Weather conditions varied seasonally and annually. In all years except 2005, precipitation was greater in spring than in summer (Table 1). Within the season, precipitation was not 
Table 1. Average monthly temperature $\left({ }^{\circ} \mathrm{C}\right)$ and accumulated precipitation ( $\mathrm{mm}$ ) for spring and summer months from 2002 through 2008 at Burneyville, Okla

\begin{tabular}{|c|c|c|c|c|c|c|c|c|}
\hline \multirow[b]{2}{*}{ Year } & \multirow[b]{2}{*}{ Climatic variable } & \multicolumn{7}{|c|}{ Month } \\
\hline & & March & April & May & June & July & August & September \\
\hline \multirow[t]{2}{*}{2002} & Precipitation & 11.3 & 11.8 & 4.5 & 11.0 & 3.5 & 4.8 & 4.8 \\
\hline & Temperature & 18 & 24 & 26 & 31 & 33 & 34 & 31 \\
\hline \multirow[t]{2}{*}{2003} & Precipitation & 2.5 & 1.0 & 13.0 & 7.5 & 0.5 & 6.3 & 4.8 \\
\hline & Temperature & 19 & 25 & 29 & 31 & 37 & 37 & 28 \\
\hline \multirow[t]{2}{*}{2004} & Precipitation & 3.0 & 13.3 & 2.3 & 30.0 & 12.3 & 2.3 & 2.5 \\
\hline & Temperature & 21 & 24 & 28 & 31 & 33 & 32 & 31 \\
\hline \multirow[t]{2}{*}{2005} & Precipitation & 1.0 & 1.3 & 6.3 & 3.0 & 9.8 & 12.5 & 4.0 \\
\hline & Temperature & 19 & 24 & 27 & 33 & 34 & 33 & 33 \\
\hline \multirow[t]{2}{*}{2006} & Precipitation & 9.3 & 18.8 & 6.5 & 1.3 & 0.0 & 6.5 & 4.8 \\
\hline & Temperature & 21 & 28 & 31 & 34 & 38 & 38 & 29 \\
\hline \multirow[t]{2}{*}{2007} & Precipitation & 9.8 & 3.5 & 22.8 & 19.8 & 9.8 & 5.5 & 2.3 \\
\hline & Temperature & 22 & 21 & 27 & 16 & 32 & 34 & 32 \\
\hline \multirow[t]{2}{*}{2008} & Precipitation & 14.0 & 5.8 & 8.8 & 6.0 & 1.5 & 9.0 & 3.5 \\
\hline & Temperature & 13 & 17 & 22 & 27 & 29 & 27 & 22 \\
\hline
\end{tabular}

uniformly distributed. Precipitation was poorly distributed in spring of 2003, 2004, and 2005 with greater than 50\% occurring in the last week of May and the first week of June (data not shown). Precipitation during the summer was relatively low in 2006 and 2003 and relatively high in 2004 and 2007 (Table 1). Precipitation was poorly distributed in the summer of 2004, 2005, and 2006. In fact, in 2006 more than $70 \%$ of total summer precipitation was obtained between 27 August and 4 September (data not shown).

Temperatures during spring varied among years, and 2008 had the lowest daily mean from 1 March through 21 June $\left(17^{\circ} \mathrm{C}\right)$. Spring of 2006 was the hottest with daily temperatures averaging $28{ }^{\circ} \mathrm{C}$ from 1 March through 21 June. Similarly, summer temperature varied among years, with the mean temperature of $35^{\circ} \mathrm{C}$ in 2006 being the hottest, and temperatures $\leq 28^{\circ} \mathrm{C}$ in 2007 and 2008 being the coldest. In other years, mean summer temperature averaged $\geq 32^{\circ} \mathrm{C}$.

\section{Forage Yield}

Forage yield was affected by interaction of $\mathrm{N}$ fertilizer rate, harvest season, and year (P $=0.0004$ ) (Table 2 ). The interaction was partly related to non-N fertilized Bermuda grass in 2004 and 2005 having greater spring yields compared to N-fertilized Bermuda grass in 2002, 2006, 2007, and 2008 (Table 3). Across N rates, the greatest and lowest spring harvests were obtained in 2004 and 2006, respectively (Table 3). Positive yield responses to $\mathrm{N}$ fertilizer occurred in relatively wet years, 2003 and 2004. In 2003, the greatest forage yields were obtained at $224 \mathrm{~kg} \mathrm{~N} \mathrm{ha}^{-1}$. In 2004 and 2008, forage yields were greater for all $\mathrm{N}$-fertilized Bermuda grass treatments than for the non-N-fertilized Bermuda grass control.

Nitrogen fertilizer rate increased summer forage yields in 2002, 2003, 2004, and 2008 (Table 3). Whereas the first increment of $112 \mathrm{~kg} \mathrm{~N} \mathrm{ha}^{-1}$ produced the greatest yields in 2003 
Table 2. Analysis of variance $p$ values for $N$ rate, year, harvest, and interaction on several observed parameters

\begin{tabular}{|c|c|c|c|c|c|c|c|c|c|}
\hline Variable & Yield & $\mathrm{CP}$ & TDN & NDF & ADF & $P$ & K & $\mathrm{Ca}$ & $\mathrm{Mg}$ \\
\hline $\mathrm{N}$ fertilizer $(\mathrm{N})$ & 0.2145 & $<.0001$ & $<.0001$ & $<.0001$ & $<.0001$ & $<.0001$ & 0.1394 & 0.0097 & $<.0001$ \\
\hline Year & $<.0001$ & $<.0001$ & 0.3445 & $<.0001$ & 0.3454 & $<.0001$ & $<.0001$ & $<.0001$ & $<.0001$ \\
\hline Harvest & $<.0001$ & $<.0001$ & $<.0001$ & $<.0001$ & $<.0001$ & $<.0001$ & $<.0001$ & 0.2229 & 0.0451 \\
\hline $\mathrm{N} \times$ Year & $<.0001$ & 0.2091 & 0.62 & 0.9247 & 0.62 & 0.2264 & 0.0065 & $<.0001$ & 0.0005 \\
\hline $\mathrm{N} \times$ Harvest & 0.3893 & 0.0017 & 0.9146 & 0.1854 & 0.915 & 0.1818 & 0.1586 & 0.0041 & 0.1421 \\
\hline Harvest $\times$ Year & $<.0001$ & $<.0001$ & $<.0001$ & $<.0001$ & $<.0001$ & 0.0043 & 0.0005 & $<.0001$ & 0.0198 \\
\hline $\mathrm{N} \times$ Harvest $\times$ Year & 0.0004 & 0.8848 & 0.9939 & 0.8875 & 0.994 & 0.9986 & 0.9944 & 0.9822 & 0.7845 \\
\hline
\end{tabular}

Table 3. Spring and summer forage yield $\left(\mathrm{kg} \mathrm{ha}^{-1}\right)$ of Midland Bermuda grass on a Minco fine, sandy loam soil in southern Oklahoma, USA

\begin{tabular}{|c|c|c|c|c|c|c|c|c|}
\hline \multirow[b]{2}{*}{ Harvest season } & \multirow[b]{2}{*}{$\mathrm{N}$ rate } & \multicolumn{6}{|c|}{ Year } & \multirow[b]{2}{*}{2008} \\
\hline & & 2002 & 2003 & 2004 & 2005 & 2006 & 2007 & \\
\hline \multirow[t]{7}{*}{ Spring } & 0 & 3817 & 3763 & 5347 & 7670 & 2300 & 3440 & 637 \\
\hline & 100 & 4817 & 6190 & 8480 & 4003 & 1820 & 2493 & 4713 \\
\hline & 200 & 3667 & 7337 & 8117 & 1397 & 463 & 2153 & 4607 \\
\hline & $200^{\mathrm{a}}$ & 3610 & 5927 & 8023 & 3460 & 1957 & 2230 & 2857 \\
\hline & 300 & 4233 & 6210 & 8033 & 1317 & 663 & 2310 & 4427 \\
\hline & 400 & 3663 & 4967 & 8830 & 3643 & 1277 & 2590 & 3700 \\
\hline & $400^{a}$ & 4397 & 6670 & 7563 & 2997 & 2070 & 1793 & 2750 \\
\hline \multirow[t]{8}{*}{ Summer } & 0 & 5065 & 1422 & 5637 & 2133 & 4700 & 3296 & 694 \\
\hline & 100 & 5787 & 1833 & 6947 & 1948 & 5057 & 3436 & 968 \\
\hline & 200 & 6045 & 1808 & 7687 & 673 & 2813 & 2080 & 1096 \\
\hline & $200^{\mathrm{a}}$ & 5360 & 2380 & 7207 & 1292 & 6537 & 3212 & 1113 \\
\hline & 300 & 5877 & 1815 & 7953 & 603 & 4770 & 2733 & 1059 \\
\hline & 400 & 5483 & 1855 & 7060 & 1442 & 4033 & 2948 & 1037 \\
\hline & $400^{a}$ & 5562 & 2327 & 6623 & 1607 & 5970 & 3349 & 1026 \\
\hline & SE & & & & 539 & & & \\
\hline
\end{tabular}

a. Split-applied N; SE, standard error.

and 2008, $224 \mathrm{~kg} \mathrm{~N} \mathrm{ha}^{-1}$ and $336 \mathrm{~kg} \mathrm{~N} \mathrm{ha}^{-1}$ rates produced greatest yields in 2002 and 2004, respectively. In other years, no clear yield response patterns were observed with increasing $\mathrm{N}$ fertilizer rate.

\section{Forage Crude Protein}

Crude protein content depended on interaction of harvest season and $\mathrm{N}$ rate $(P=0.0017)$ (Figure 1) and harvest season and year $(P<0.0001)$ (Figure 2$)$. Crude protein content of un- 


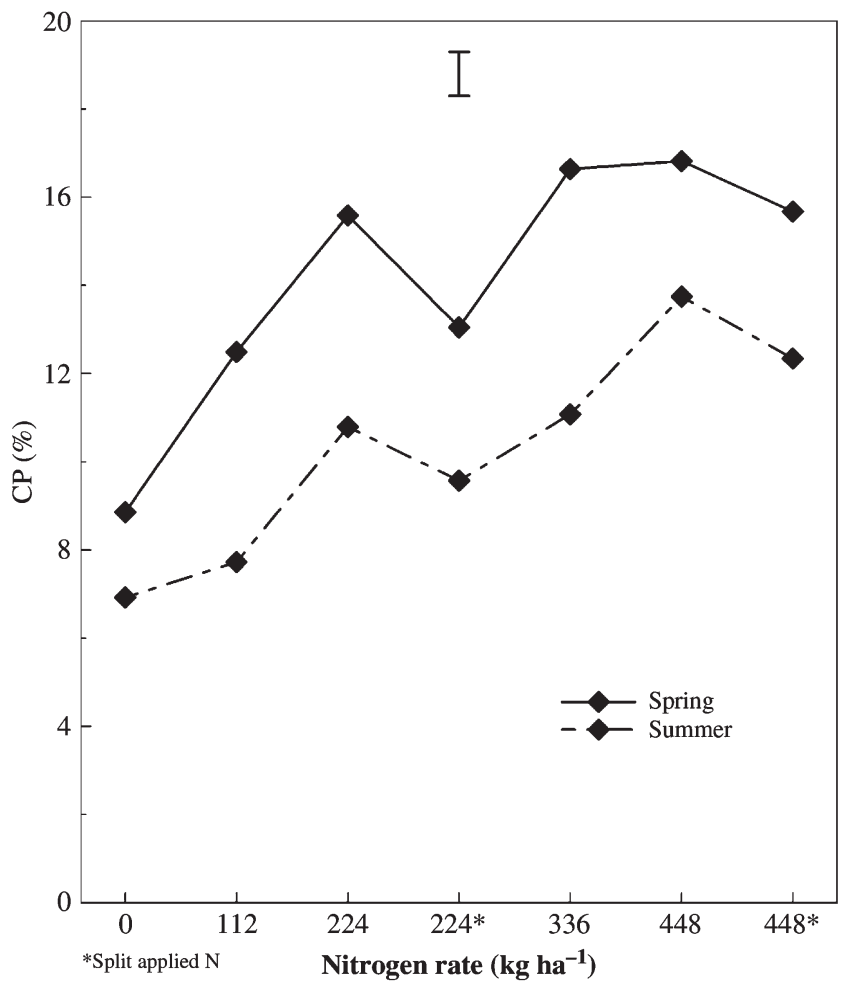

Figure 1. Effect of $\mathrm{N}$ fertilization and harvest season on $\mathrm{CP}$ of Midland Bermuda grass on a Minco fine, sandy loam in southern Oklahoma. Values are means $(n=3)$. ( $I=$ standard error.)

fertilized Bermuda grass was 9\% in spring and 7\% in summer. Application of $\mathrm{N}$ increased $\mathrm{CP}$ of both spring and summer harvested forage. There is an almost linear increase in $\mathrm{CP}$ with $\mathrm{N}$ fertilization up to $224 \mathrm{~kg} \mathrm{~N} \mathrm{ha}^{-1}$. Applying $224 \mathrm{~kg} \mathrm{~N} \mathrm{ha}^{-1}$ increased CP from $8.8 \%$ to $15.6 \%$ in spring forage, an increase of $78 \%$. Additional $112 \mathrm{~kg} \mathrm{~N} \mathrm{ha}^{-1}$ resulted in a $7 \%$ increase in CP for a total of $16.6 \%$. In summer forage, $224 \mathrm{~kg} \mathrm{~N} \mathrm{ha}^{-1}$ increased CP by $56 \%$ from $6.9 \%$ to $10.8 \%$. At $336 \mathrm{~kg} \mathrm{~N} \mathrm{ha}^{-1}, \mathrm{CP}$ in summer forage was slightly greater at $11.1 \%$. At the greatest $\mathrm{N}$ fertilizer rate of $448 \mathrm{~kg} \mathrm{~N} \mathrm{ha}^{-1}, \mathrm{CP}$ content in spring forage was similar to that at $336 \mathrm{~kg} \mathrm{~N} \mathrm{ha}^{-1}$. However, during the summer, $448 \mathrm{~kg} \mathrm{~N} \mathrm{ha}^{-1}$ increased CP content by $23 \%$ from $11.1 \%$ to $13.7 \%$. Depending on $\mathrm{N}$ fertilizer rate applied, spring forage contained $18-40 \%$ more CP than summer forage. One-time application of $\mathrm{N}$ in spring resulted in about $10 \%$ more CP content in summer forage compared to split-applied N. Across treatment, there is an increasing trend in $\mathrm{CP}$ content with year for both spring and harvest forage. While differences in CP between spring and summer seasons were low in 2003, 2005, and 2008, the differences were wide and ranged between $35 \%$ and $88 \%$ in other years. Compared to other years, CP content was relatively greater in 2006 and 2005 for spring and summer forages, respectively.

\section{Total Digestible Nutrient and Forage Fiber Content}

Total digestible nutrient $(\mathrm{TDN})$ depended on $\mathrm{N}$ rate $(P<0.0001)$ [Figure $3(\mathrm{a})$ ] and harvest season and year $(P=0.0001)$ [Figure $4(\mathrm{a})$ ]. Across years, unfertilized Bermuda grass TDN 


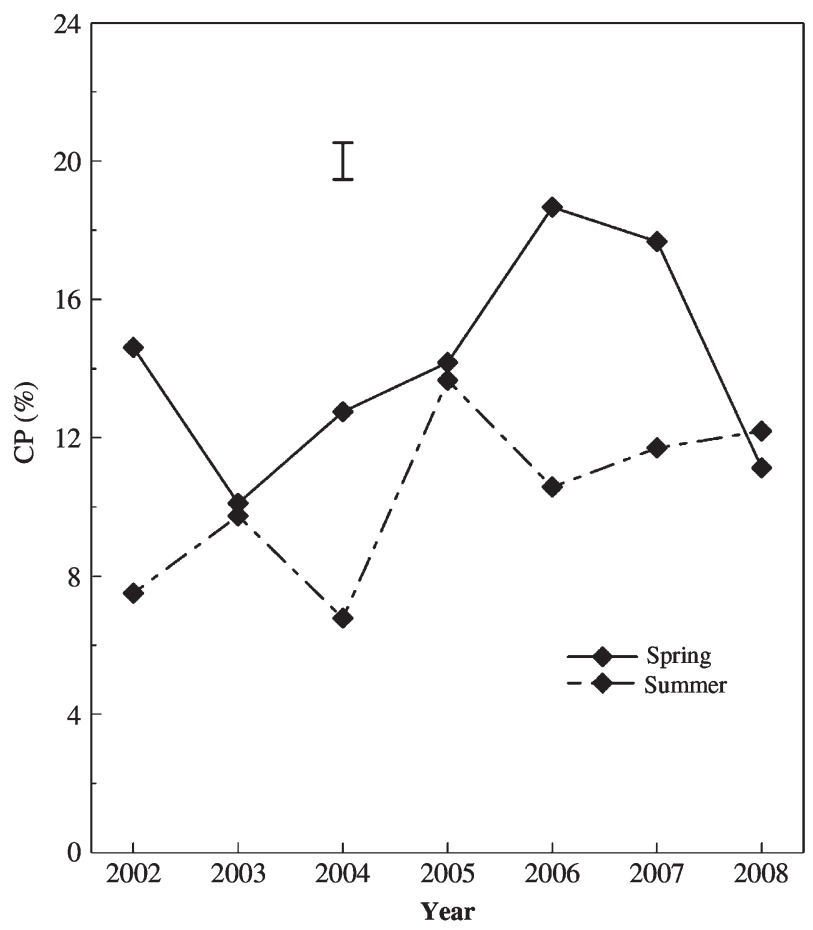

Figure 2. Crude protein content of spring- and summer-harvested Midland Bermuda grass on a Minco fine, sandy loam in southern Oklahoma. Values are means $(n=3)$. ( $I=$ standard error.)

content averaged $60 \%$. Total digestible nutrient increased with $\mathrm{N}$ fertilization and reached $64 \%$ at application rate of $448 \mathrm{~kg} \mathrm{~N} \mathrm{ha}^{-1}$. Compared to single-applied $\mathrm{N}$, split application of 224 and $448 \mathrm{~kg} \mathrm{~N} \mathrm{ha}^{-1}$ reduced TDN by $2 \%$ and $1 \%$, respectively. Total digestible nutrient in spring forage differed among years and was $62 \%$ in $2005,65 \%$ in 2006 , and $61 \%$ in 2008. Total digestible nutrient contents for summer forage were $63 \%, 60 \%, 61 \%$, and $63 \%$ in 2005, 2006, 2007, and 2008, respectively.

Both NDF and ADF were significantly reduced $(P<0.0001)$ by $\mathrm{N}$ fertilization [Figures $3(\mathrm{~b})$ and 3(c)]. Unfertilized Bermuda grass had NDF and ADF content that averaged 70\% and $36 \%$, respectively. Application of N reduced NDF and with $\mathrm{N}$ rates of $448 \mathrm{~kg} / \mathrm{ha}, \mathrm{NDF}$ dropped to $63 \%$. Nitrogen applied as split reduced NDF to a lower degree than single-applied $\mathrm{N}$ and especially for $200 \mathrm{~kg} \mathrm{~N} \mathrm{ha}^{-1}$. At fertilizer rates of rates of $448 \mathrm{~kg} \mathrm{~N} \mathrm{ha}^{-1}$, ADF content dropped by 4 units to reach $32 \%$. Nitrogen applied as split at $200 \mathrm{~kg} \mathrm{~N} \mathrm{ha}^{-1}$ gave ADF content greater than that from the same rate applied once. Harvest season and year affected NDF and ADF $(P<0.0001)$. The trend for NDF [Figure 4(b)] and ADF [Figure 4(c)] during the years was opposite that shown by TDN. The summer forage of 2006 and 2007 had greater NDF and ADF than spring forage the same years. In 2005 and 2008, NDF and ADF for spring and summer forage harvest were similar.

\section{Forage Macronutrient Concentrations}

Except for forage $\mathrm{K}$ concentration, $\mathrm{N}$ application significantly increased forage $\mathrm{P}, \mathrm{Mg}$, and Ca concentrations $(P<0.01)$ (Table 4$)$. However, effect on $\mathrm{K}, \mathrm{Mg}$, and Ca concentration is 

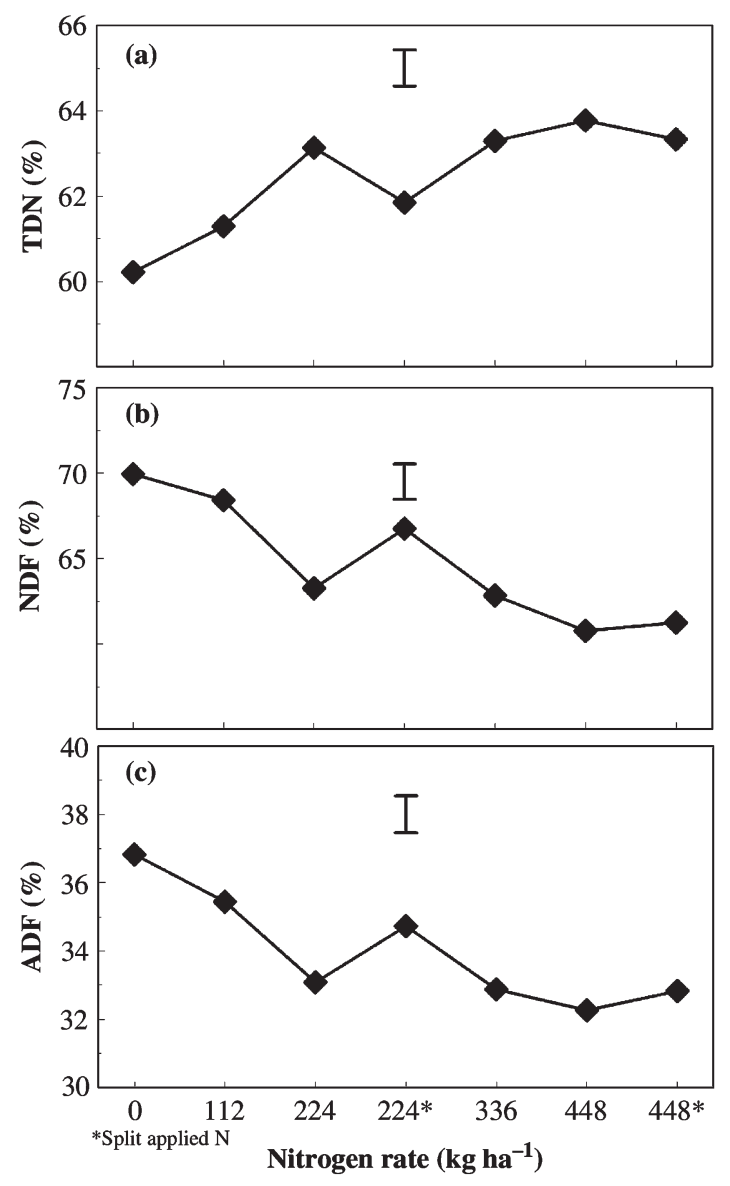

Figure 3. Effect of $N$ fertilization on forage TDN, NDF, and ADF concentrations of Midland Bermuda grass on a Minco fine, sandy loam in southern Oklahoma. Values are means $(n=3)$. ( $I=$ standard error.)

reported as an interaction with year. Unfertilized Bermuda grass had P concentration of $0.22 \%$ (Table 4). Single application of $\mathrm{N}$ in spring increased $\mathrm{P}$ concentration by between $9 \%$ and $22 \%$. At $\mathrm{N}$ fertilizer rate of $448 \mathrm{~kg} \mathrm{ha}^{-1}, \mathrm{P}$ concentration in forage increased and reached $0.27 \%$. Split application of $\mathrm{N}$ increased forage $\mathrm{P}$ more than one-time application. Bermuda grass receiving a single application of $\mathrm{N}$ at $200 \mathrm{~kg} \mathrm{ha}^{-1}$ had $\mathrm{P}$ concentration of $0.27 \%$, while that receiving split application had $0.29 \%$. Similarly, Bermuda grass receiving $400 \mathrm{~kg} \mathrm{~N} \mathrm{ha}^{-1}$ in a single application or as split application had P concentrations of $0.20 \%$ and $0.25 \%$, respectively.

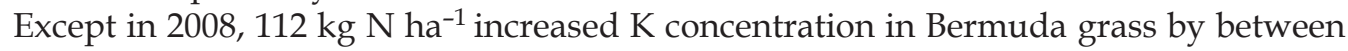
$7 \%$ to $24 \%$ (Figure 5). Further N application increased K concentration only in 2005. For all $\mathrm{N}$ rates greater than $112 \mathrm{~kg} \mathrm{ha}^{-1}$, forage $\mathrm{K}$ concentration was $\leq 1.5 \%$ in 2004, $\sim 2 \%$ in 2006 and 2008, and $\geq 2 \%$ in 2005 and 2007. Nitrogen fertilizer increased forage Ca in all years except in 2007 (Figure 5). Forage Ca concentrations averaging $>0.5 \%$ in 2005 and 2006 were high compared to $<0.4 \%$ observed in other years. Forage $\mathrm{Mg}$ concentration was the mineral element most responsive to $\mathrm{N}$ fertilization and application method (Figure 5). Except in 2005, where $\mathrm{Mg}$ concentration increased by $12 \%$ from application of $112 \mathrm{~kg} \mathrm{~N} \mathrm{ha}^{-1}$, the 


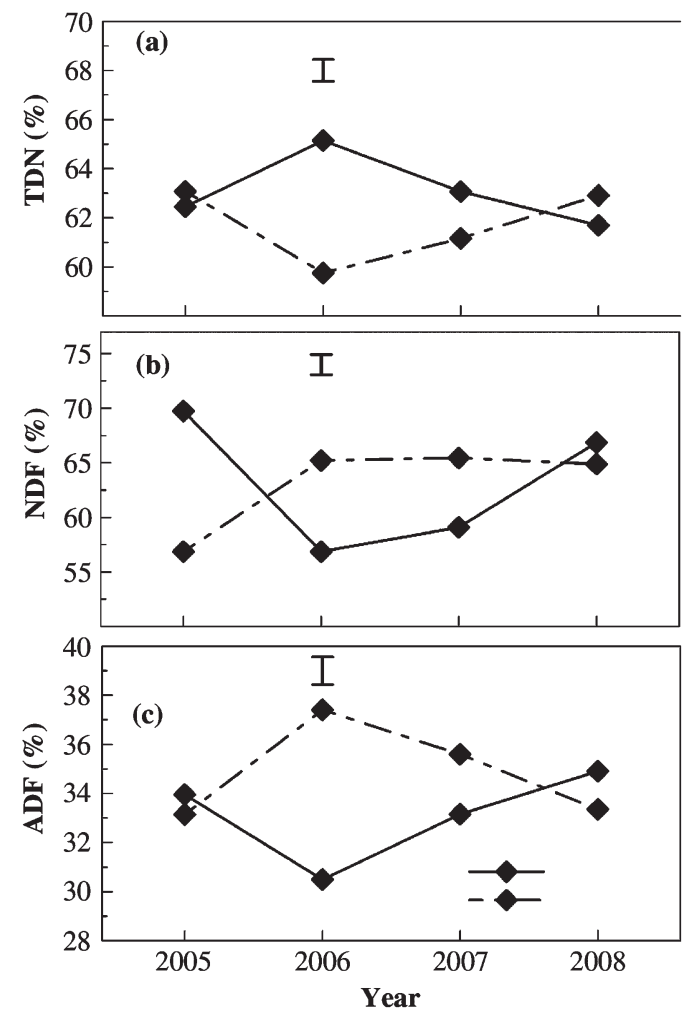

Figure 4. Spring and summer forage TDN, NDF, and ADF of Midland Bermuda grass on a Minco fine, sandy loam in southern Oklahoma. Values are means $(n=3)$. ( $I=$ standard error.)

Table 4. Effect of $\mathrm{N}$ fertilizer rate on forage $\mathrm{P}, \mathrm{K}, \mathrm{Mg}$, and Ca content of Midland Bermuda grass on a Minco fine, sandy loam soil in southern Oklahoma, USA

\begin{tabular}{lcccc}
\hline & \multicolumn{4}{c}{ Nutrient (\%) } \\
\cline { 2 - 5 } $\mathrm{N}$ rate $\left(\mathrm{kg} \mathrm{ha}^{-1}\right)$ & $\mathrm{P}$ & $\mathrm{K}$ & $\mathrm{Mg}$ & $\mathrm{Ca}$ \\
\hline 0 & 0.224 & 1.763 & 0.178 & 0.393 \\
112 & 0.245 & 1.943 & 0.228 & 0.401 \\
224 & 0.273 & 1.945 & 0.325 & 0.445 \\
$224 a$ & 0.288 & 1.920 & 0.260 & 0.441 \\
336 & 0.253 & 1.907 & 0.339 & 0.448 \\
448 & 0.269 & 1.861 & 0.368 & 0.473 \\
$448 a$ & 0.282 & 1.881 & 0.347 & 0.479 \\
$\mathrm{SE}$ & 0.004 & 0.047 & 0.019 & 0.016 \\
$p$ value & $<0.0001$ & 0.1394 & $<0.0001$ & 0.0097 \\
\hline
\end{tabular}

a. Split-applied N.

increase was more than $25 \%$ in other years. Single application of $224 \mathrm{~kg} \mathrm{~N} \mathrm{ha}^{-1}$ and $448 \mathrm{~kg}$ $\mathrm{N} \mathrm{ha}^{-1}$ increased $\mathrm{Mg}$ concentration by between $41 \%$ and $115 \%$ and between $60 \%$ and $143 \%$, respectively. Except in 2004, split application of $224 \mathrm{~kg} \mathrm{~N}$ ha $^{-1}$ reduced $\mathrm{Mg}$ concentration to $19 \%$ of that observed for a single application in all years. Compared to similar rates ap- 

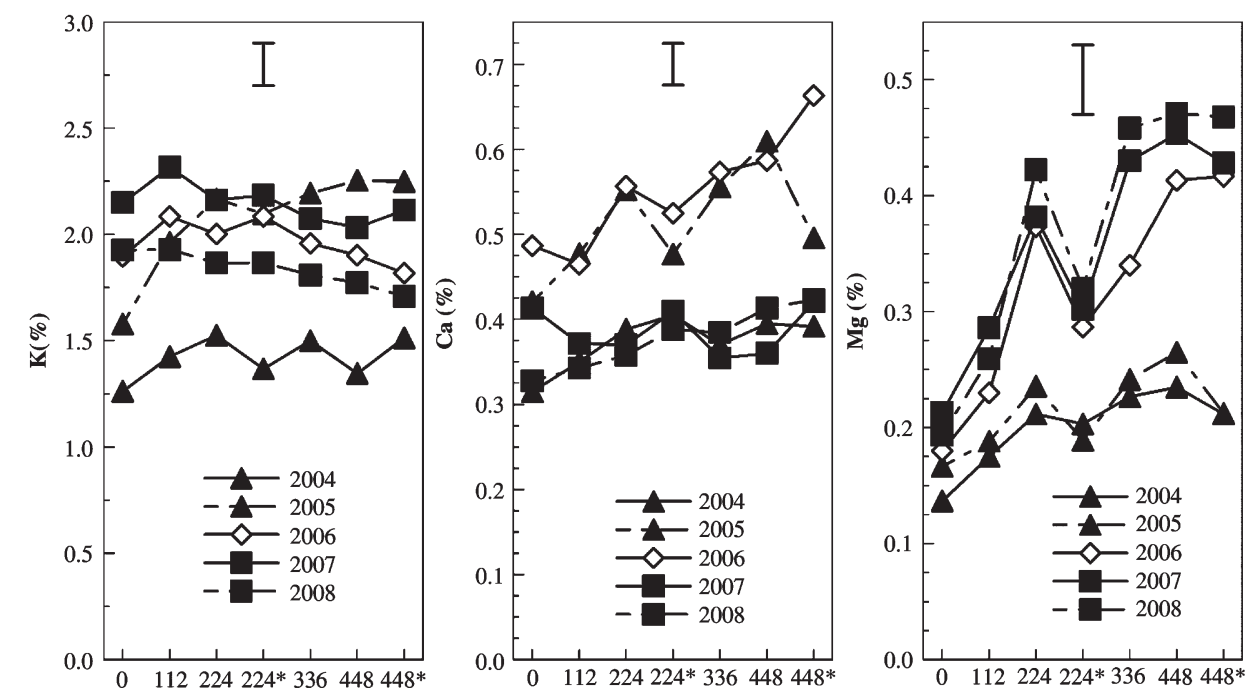

Figure 5. Effects of $\mathrm{N}$ fertilization on forage $\mathrm{K}, \mathrm{Ca}$, and $\mathrm{Mg}$ concentrations in different years for harvested Midland Bermuda grass on a Minco fine, sandy loam. Values are means $(n=3)$. ( $I=$ standard error.)

plied once, split application of $224 \mathrm{~kg} \mathrm{~N} \mathrm{ha}^{-1}$ caused a greater reduction in forage $\mathrm{Mg}$ than that caused by $448 \mathrm{~kg} \mathrm{~N}^{-1}$.

Bermuda grass forage concentration of $\mathrm{P}, \mathrm{K}, \mathrm{Mg}$, and Ca was affected by an interaction of harvest time and year $(P<0.02)$. In general, summer forage usually contained relatively lower concentrations than spring forage except for Mg and Ca in 2005 and 2008 (Figure 6). Whereas there was a general increase in the four mineral concentrations in the forage from 2004 to 2005, only Mg concentration continued increasing in later years as others leveled off or dropped (Figure 6). Percentage reduction in summer forage mineral concentration was greatest for $\mathrm{K}$ in all years.

\section{Discussion}

Differences in precipitation and temperatures among harvest season and years impacted Bermuda grass yield response to $\mathrm{N}$ fertilizer rates. The consistent increase in yield in response to $\mathrm{N}$ fertilization observed in both the spring and summer of 2003 and 2004 may be a result of a slightly better distributed rainfall during these years. High early summer precipitation and an extended growth period prior to harvest may be responsible for high summer yield in 2004. Despite an extremely hot summer, forage yield during the summer of 2006 was high. This may be due to residual moisture from precipitation a few days before spring harvest and a 2-month summer growth period prior to harvest. High yields in unfertilized forage in spring of 2005 and summer of 2006 could be attributed to dry conditions. Under such conditions, fertilizer response may be negative as previously reported for grass growth response to fertilizer application under dry and hot conditions (Prasertsak and Fukai 1997).

Despite variability in weather, $\mathrm{N}$ fertilization consistently had a positive impact on Bermuda grass forage quality. Increased forage $\mathrm{CP}$ and TDN and reduced ADF and NDF with $\mathrm{N}$ fertilization could be a result of better plant growth. Nitrogen fertilization may have resulted in increased leaf $\mathrm{N}$, tissue protein, and digestible carbohydrates as reported ear- 

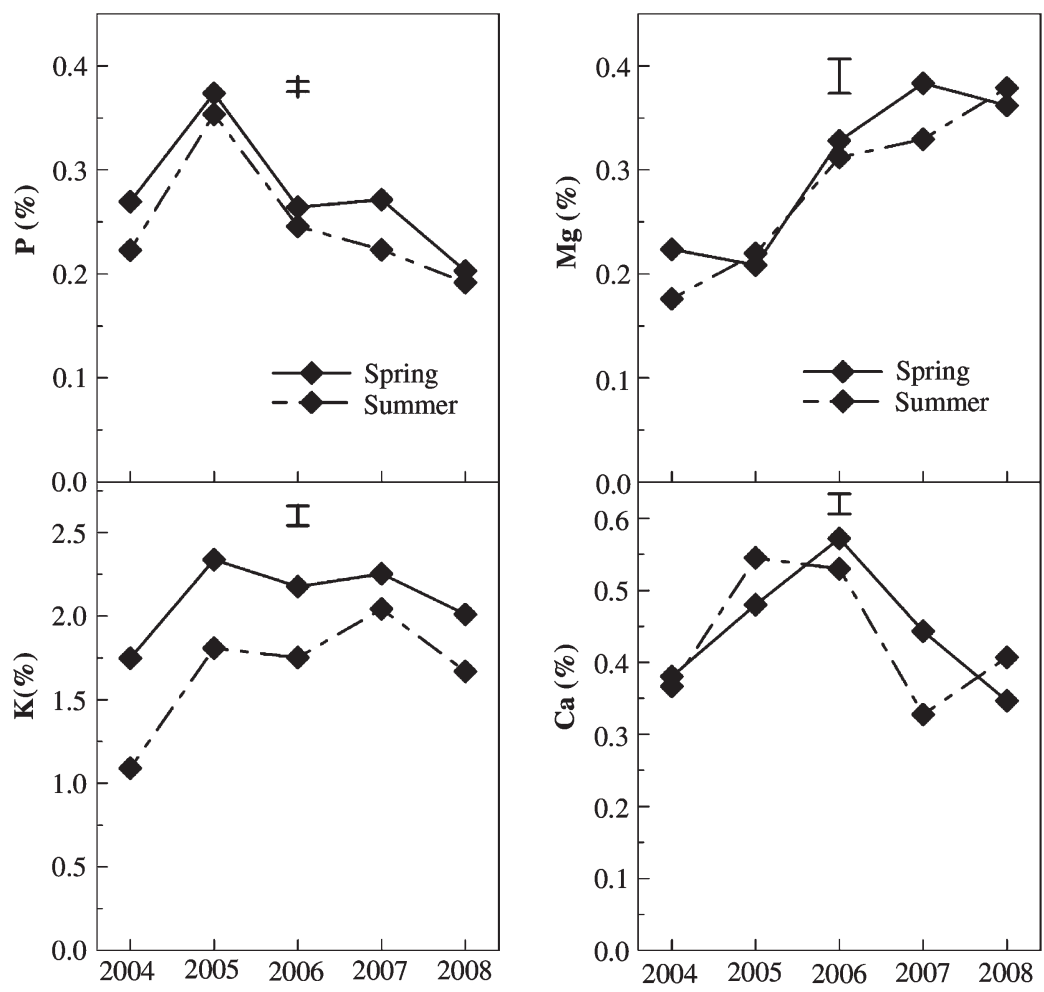

Figure 6. Effect of $\mathrm{N}$ fertilization on forage $\mathrm{P}, \mathrm{K}, \mathrm{Ca}$, and $\mathrm{Mg}$ concentrations of spring- and summerharvested Midland Bermuda grass on a Minco fine, sandy loam. Values are means $(n=3)$. ( $I=$ standard error.)

lier for coastal Bermuda grass (Fribourg et al. 1979; Kellogg et al. 1994). High precipitation in spring may have let to increased vegetative growth, leaf/stem ratio, CP, and TDN and reduced ADF and NDF content than observed in summer forage. Crude protein that reached $\sim 17 \%$ with $448 \mathrm{~kg} \mathrm{~N} \mathrm{ha}^{-1}$ is not surprising because similar content was reported for Coastal Bermuda grass receiving $550 \mathrm{~kg} \mathrm{~N} \mathrm{ha}^{-1}$ and cut at 3- to 4-week intervals (Burton, Jackson, and Hart 1963). In 2006, high precipitation in early spring may be responsible for high CP and TDN content and low ADF and NDF in spring forage compared to other years. A comparatively hot and dry summer in 2006 could explain the high NDF and ADF and low TDN in the forage. High temperature and moisture stress are reported to reduce forage quality by decreasing leaf/stem ratio (Fick, Holt, and Lugg 1988), increasing lignification (Gitz et al. 2006), and increasing ADF and NDF contents (Turner 1979). Variation in forage quality between years may be explained by differences in climatic conditions. For example, while high CP and TDN contents for spring forage could be explained by the relatively high precipitation in 2006, low summer temperatures may be responsible for high $\mathrm{CP}$ and low ADF observed for summer forage in 2008.

Low precipitation and high summer temperature has potential to reduce the efficiency of the plant to take up and utilize summer-applied $\mathrm{N}$ and could explain the lack of response observed in split-applied $\mathrm{N}$. One-time application of $\mathrm{N}$ in spring when precipitation is high may increase root proliferation, root density, soil-root contact, nutrient element uptake, and plant growth. Low temperature and precipitation may have led to better 
stomatal operation, increased transpiration, and water and nutrient uptake. Evapotranspirational demand has been pointed out as a common mechanism used for nutrient uptake by forage crops (Blevins and Barker 2007). The relatively low nutrient concentrations in summer forage could be attributed to hot and dry conditions, which reduce plant nutrient demand, nutrient uptake, and possibly remobilization of nutrients to belowground structure. Reduced growth and nutrient remobilization to belowground structures was pointed out as a survival strategy used by forage crops undergoing drought stress (Blevins and Barker 2007). Higher reduction in $\mathrm{K}$ compared to $\mathrm{Ca}$ and $\mathrm{Mg}$ in summer forage may be a result of low plant-available $\mathrm{K}$ and $\mathrm{K}$ uptake. Increased $\mathrm{K}$ fixation and reduced plant-available $\mathrm{K}$ in soils with low moisture is reported elsewhere (Kuchenbuch, Claasen, and Jungk 1986). Nitrogen application increased forage $\mathrm{P}, \mathrm{Mg}$, and $\mathrm{Ca}$ concentration to levels within ranges considered optimal for grazing livestock (NRC 1996). Its minimal effect on K may significantly reduce tetany ratio $[\mathrm{K} /(\mathrm{Mg}+\mathrm{Ca})]$ of the forage. Low tetany ratio $(<2.2)$ reduce potential for appearance of tetany in animal grazing the forage or feeding on its hay.

\section{Conclusions}

Wide variations in weather conditions from year to year results in variable forage yield at similar $\mathrm{N}$ fertilizer rates. Also, yield in response to $\mathrm{N}$ varied positively during wet seasons. However, despite the wide variations in yield, $\mathrm{N}$ fertilization consistently increased $\mathrm{CP}$ and TDN and decreased ADF and NDF. The yearly differences in forage quality may indicate that response to $\mathrm{N}$ should be looked at on a yearly basis so that fluctuations in $\mathrm{N}$ effect caused by environmental conditions such as precipitation can be captured. This is critical if the effects of $\mathrm{N}$ fertilization on forage quality falls below the levels expected to meet nutritional needs of grazing animals. Despite the low tetany risk even in the control treatment, reduction of tetany ratio with $\mathrm{N}$ fertilizer may be beneficial especially where stockpiling Bermuda grass for grazing in late fall and autumn is being considered. High nutrient content in shoots at this time may allow for retention of some nutrient when element remobilization to the underground occurs during onset of fall/winter. Because forage yield and quality responses to spring applied $\mathrm{N}$ were greater than that of a split $\mathrm{N}$ fertilization that includes a summer application, a single one-time $\mathrm{N}$ fertilizer application should be recommended for the semi-arid, southern Great Plains of the United States.

\section{References}

Blevins, D. G., and D. J. Barker. 2007. Nutrients and water in forage crops. In Forages. The science of grassland agriculture II, ed. R. F. Barnes, C. J. Nelson, K. J. Moore, and M. Collins, 67-80. Ames, Iowa: Blackwell.

Brink, G. E., G. A. Pederson, and K. R. Sistani. 2005. Nutrient uptake of swine effluent- fertilized bermuda grass during spring and summer growth. Journal of Plant Nutrition 28: 1337-1346.

Brink, G. E., K. R. Sistani, and D. E. Rowe. 2004. Nutrient uptake of hybrid and common bermuda grass fertilized with broiler litter. Agronomy Journal 96:1509-1515.

Burton, G. W., J. E. Jackson, and R. H. Hart. 1963. Effect of frequency and nitrogen on yield, in vitro digestibility, and protein, fiber, and carotene content of coastal bermuda grass. Agronomy Journal 55:500-502.

Fick, G. W., D. A. Holt, and D. G. Lugg. 1988. Environmental physiology and crop growth. In Alfalfa and alfalfa improvement, ed. A. A. Hanson, D. K. Barnes, and R. R. Hill Jr., 163-194. Madison, WI: American Society of Agronomy. 
Fribourg, H. A., K. M. Barth, J. B. McLaren, L. A. Carver, J. T. Connell, and J. M. Bryan. 1979. Seasonal trends of in vitro matter digestibility of $\mathrm{N}$-fertilized bermuda grass and of orchard grass-Ladino pastures. Agronomy Journal 71:117-120.

Fribourg, H. A., N. C. Edwards, and K. M. Barth. 1971. In vitro dry-matter digestibility of 'Midland' bermuda grass grown at several levels of N fertilization. Agronomy Journal 63:786-788.

Fribourg, H. A., J. B. McLaren, K. M. Barth, J. M. Bryan, and J. T. Connell. 1979. Productivity and quality of bermuda grass and orchard grass-ladino clover pastures for beef steers. Agronomy Journal 71:315-320.

Gitz, D. C., J. C. Ritchie, D. T. Krizek, T. L. Springer, J. B. Reeves III, and V. Reddy. 2006. Effect of temperature and $\mathrm{CO} 2$ on forage nutritive value of 'Pete' eastern gamagrass. In Proceedings of the Fifth Eastern Native Grass Symposium, ed. M. A. Sanderson, P. Adler, S. Goslee, J. C. Ritchie, H. Skinner, and K. Soder, 107-114. Washington, DC: USDA NRSC and USDA ARS.

Griffin, J. L., and V. H. Watson. 1982. Production and quality of four bermuda grasses as influenced by rainfall patterns. Agronomy Journal 74:1044-1047.

Harlan, J. R., G. W. Burton, and W. C. Elder. 1954. Midland bermuda grass (Bulletin No. B-416). Stillwater, Oklahoma: Oklahoma Agricultural Experiment Station.

Helton, T. J., T. J. Butler, M. L. McFarland, F. M. Hons, S. Mukhtar, and J. P. Muir. 2008. Effects of dairy manure compost and supplemental inorganic fertilizer on Coastal bermuda grass. Agronomy Journal 100:924-930.

Henderson, M. S., and D. L. Robinson. 1982. Environmental influences on yield and in vitro true digestibility of warm-season perennial grasses and the relationship to fiber components. Agronomy Journal 74:943-946.

Isaac, R. 1990. Metals in plants: Method 985. In Official methods of analysis of the Association of Official Analytical Chemists, 15th ed., ed. K. Helrich. Arlington, Va.: AOAC.

Kellogg, D. W., R. C. Gliedt, E. K. Vaugh, K. F. Harrison, Z. B. Johnson, O. T. Stallcup, and B. J. Hankins. 1994. Effect of increased fertilization on fiber and mineral content of Bermuda cultivars (Special Report 163). Fayetteville, Arkansas: Agricultural Experiment Station, Division of Agriculture, University of Arkansas.

Kuchenbuch, R., N. Claasen, and A. Jungk. 1986. Potassium availability in relation to soil moisture, II: Calculation by means of a mathematical simulation model. Plant and Soil 95:223-243.

Mathias, E. L., O. L. Bennett, and P. E. Lundberg. 1978. Fertilization effects on yield and N concentration of Midland bermuda grass. Agronomy Journal 70:973-976.

Morris, H. D., and J. F. Celecia. 1962. Effect of time of fertilizer application on yield and nutrient uptake of coastal bermuda on cecil sandy loam. Agronomy Journal 54:335-338.

NIRS Forage and Feed Testing Consortium. 2007. Grass hay calibration (gh50-2). Madison: University of Wisconsin.

NRC. 1996. Nutrient requirement of beef cattle, 7th ed. Washington, D.C.: National Academy Press.

Osborne, S. L., W. R. Raun, G. V. Johnson, J. L. Rogers, and W. Altom. 1999. Bermuda grass response to high nitrogen rates, source, and season of application. Agronomy Journal 91:438-444.

Overman, A. R., M. A. Sanderson, and R. M. Jones. 1993. Logistic response of bermuda grass and bunchgrass cultivars to applied nitrogen. Agronomy Journal 85:541-545.

Padmore, J. M. 1990. Fat (crude) or ether extract in animal feed (Method 920.39). In Official methods of analysis of the Association of Official Analytical Chemists, 15th ed., K. Helrich. Arlington, Va.: AOAC.

Prasertsak, A., and S. Fukai. 1997 Nitrogen availability and water stress interaction on rice growth and yield. Field Crop Research 52:249-260.

Prine, G. M., and G. W. Burton. 1956. The effect of nitrogen rate and clipping frequency upon the yield, protein content, and certain morphological characteristics of bermuda grass (Cynodon dactylon (L.) Pers). Agronomy Journal 48:296-301. 
Read, J. J., G. E. Brink, J. L. Oldham, W. L. Kingery, and K. R. Sistani. 2006. Effects of broiler litter and nitrogen fertilization on uptake of major nutrients by coastal bermuda grass. Agronomy Journal 98:1065-1072.

Sanderson, M. A., R. M. Jones, and J. S. Newman. 1991. Productivity of 10 warm-season perennial grasses over several years in central Texas (Bulletin 1695). College Station, Texas: Texas Agricultural Experiment Station.

Taliaferro, C. M., F. P. Horn, B. B. Tucker, R. Totusek, and R. D. Morrison. 1975. Performance of three warm-season perennial grasses and a native range mixture as influenced by $\mathrm{N}$ and $\mathrm{P}$ fertilization. Agronomy Journal 67:289-292.

Taliaferro, C. M., F. M. Rouquette Jr., and P. Mislevy. 2004. Bermuda grass and stargrass. In Warmseason (C4) grasses, L. E. Moser et al. Madison, WI: ASA, CSSA, SSSA.

Turner, N. C. 1979. Drought resistance and adaptation to water deficit in crop plants. In Stress physiology in crop plants, ed. H. Mussell and R. C. Staples, 343-372. New York: John Wiley and Sons.

West, C. P. 1990. A proposed growth stage system for bermuda grass. In Proceedings of the American Forage and Grasslands Council, 38-42. Georgetown, Texas: AFGC.

Wilkinson, S. R., and G. W. Langdale. 1974. Fertility needs of the warm-season grasses. In Forage fertilization, ed. D. A. Mays. Madison, WI: ASA, CSSA, SSSA.

Woodhouse Jr., W. W. 1969. Long-term fertility requirements of Coastal Bermuda II: Nitrogen, phosphorus and lime. Agronomy Journal 61:251-256. 